\title{
New steroidal saponins from the sponge Erylus lendenfeldi
}

\author{
Mostafa Fouad, ${ }^{\text {a,b }}$ Khaled Al-Trabeen, ${ }^{\mathrm{c}}$ Mohammad Badran, ${ }^{\mathrm{c}}$ Victor Wray, ${ }^{\mathrm{d}}$ RuAngelie \\ Edrada, ${ }^{\mathrm{a}}$ Peter Proksch, ${ }^{\mathrm{a}}$ and Rainer Ebel ${ }^{\mathrm{a} *}$ \\ ${ }^{a}$ Institut für Pharmazeutische Biologie, Heinrich-Heine-Universität Düsseldorf, \\ Universitätsstrasse 1, Geb. 26.23, D-40225 Düsseldorf, Germany \\ ${ }^{b}$ Permanent address: Pharmacognosy Department, Faculty of Pharmacy, El-Minia University, \\ El-Minia, Egypt \\ ${ }^{c}$ Marine Science Station, University of Jordan-Yarmouk University, PO Box 195, Aqaba, Jordan \\ ${ }^{d}$ Gesellschaft für Biotechnologische Forschung $\mathrm{mbH}$, \\ Mascheroder Weg 1, D-38124 Braunschweig, Germany \\ E-mail: ebel@uni-duesseldorf.de
}

\section{Dedicated to Professor Karsten Krohn on the occasion of his $\mathbf{6 0}^{\text {th }}$ birthday}

(received 6 Apr 04; accepted 17 Aug 04; published on the web 23 Aug 04)

\begin{abstract}
Our search for biologically active marine natural products has led to the isolation of two new steroidal saponins, eryloside K (2) and eryloside L (3) together with the known antitumor and antifungal glycoside eryloside A (1) from the organic extract of the sponge Erylus lendenfeldi (Geodiidae) collected in the Red Sea. The structures of the new compounds were elucidated on the basis of comprehensive spectral analyses $\left({ }^{1} \mathrm{H},{ }^{13} \mathrm{C}\right.$, COSY, HMQC, HMBC and TOCSY NMR) as well as GC/MS analysis to infer the absolute stereochemistry of the sugar moieties. Eryloside K (2) is the 24,25-didehydro congener of 1, while eryloside L (3) features an unusual $8 \alpha, 9 \alpha$-epoxy-4 $\alpha$-methyl-8,9-secocholesta-7,9(11),14-triene skeleton which appears to be unprecedented in nature. Eryloside A (1) displayed antibacterial activity against Bacillus subtilis and Escherichia coli together with antifungal activity against Candida albicans.
\end{abstract}

Keywords: Marine sponge, steroidal saponin, saponin, antibacterial, antifungal

\section{Introduction}

Sponges of the genus Erylus have attracted the attention of natural product chemists due to the different classes of bioactive compounds present in these organisms. While glycolipids, ${ }^{1-3}$ fatty acids, ${ }^{4}$ and a polyketide ${ }^{5}$ have been described, the majority of reports focuses on steroidal or triterpenoidal saponins. Interestingly, after Kashman's initial discovery of the $4 \alpha$-methyl steroidal saponin, eryloside A (1) from the Red Sea sponge Erylus lendenfeldi, ${ }^{6}$ all further members of the eryloside family were triterpenoidal saponins derived from the lanostane 14- 
carboxylic acid aglycone, penasterol or congeners carrying additional $\mathrm{C}_{1}$ units at $\mathrm{C}-24, \mathrm{C}-25$, or both. This includes erylosides $\mathrm{C}$ and D from an unidentified Erylus sponge from New Caledonia, ${ }^{7}$ eryloside E from the Caribbean sponge Erylus goffrilleri, ${ }^{8}$ eryloside $\mathrm{F}^{9}$ and the related formoside ${ }^{10}$ as well as formoside $\mathrm{B}^{11}$ from the Caribbean species Erylus formosus, erylosides G-J from the Korean sponge Erylus nobilis, ${ }^{12}$ and nobiloside from the same species collected off the coast of Japan. ${ }^{13}$

Our investigation of a sample of Erylus lendenfeldi collected off the Jordan coast in the gulf of Aqaba, Red Sea, yielded the known eryloside A (1), and in addition, two new $4 \alpha$-methyl steroidal saponins for which we propose the names erylosides K (2) and L (3).

\section{Results and Discussion}

The sponge Erylus lendenfeldi was successively extracted with $\mathrm{MeOH}$ and acetone. The combined extracts were concentrated to dryness and partitioned between petroleum ether, EtOAc, $n-\mathrm{BuOH}$, and $\mathrm{H}_{2} \mathrm{O}$. Due to their similar chemical profiles, EtOAc and $n-\mathrm{BuOH}$ fractions were pooled and subjected to medium pressure liquid chromatography (MPLC) using silica gel as stationary phase and $\mathrm{CH}_{2} \mathrm{Cl}_{2} / \mathrm{MeOH}(70: 30)$ as mobile phase. Subsequent semi-preparative reversed phase chromatography yielded three pure compounds, namely erylosides A (1), K (2), and L (3) (Figure 1).

Eryloside A (1) was obtained as a white amorphous powder. By ESI-LC/MS, a pseudomolecular ion was observed at $m / z 739.3[\mathrm{M}+\mathrm{H}]^{+}$which in conjunction with $1 \mathrm{D}$ and 2D NMR data was compatible with the molecular formula $\mathrm{C}_{40} \mathrm{H}_{66} \mathrm{O}_{12}$. Fragment peaks due to the loss of one hexose unit $(\mathrm{m} / \mathrm{z} 577.4)$, two hexose units $(\mathrm{m} / \mathrm{z} 415.5)$, and two hexose units and water $(\mathrm{m} / \mathrm{z} 397.5)$ suggested 1 to be a monodesmosidic steroidal saponin containing two hexose moieties. In the ${ }^{1} \mathrm{H}$ NMR spectrum (see Table 1), four methyl doublets and two singulets were clearly discernible, while between 3.0 and $5.5 \mathrm{ppm}$, a number of resonances were observed, including two anomeric protons at $\delta 4.28\left(\mathrm{~d}, J=7.8 \mathrm{~Hz}, \mathrm{H}-\mathrm{l}^{\prime}\right)$ and 4.42 (d, $\left.J=7.7 \mathrm{~Hz}, \mathrm{H}-\mathrm{1}^{\prime \prime}\right)$. These findings were in agreement with 1 representing a steroidal glycoside with two sugar moieties. ${ }^{13} \mathrm{C}$ NMR and DEPT data revealed the presence of 40 carbon signals in total, 12 for the two sugar moieties, and 28 for the aglycone. The latter were divided into six methyl, nine methylene, eight methine, and five quaternary carbons. In addition to the identical molecular weight, the NMR data of 1 were very similar to those reported for eryloside $A^{6}$ (note that the original NMR data were recorded in $\mathrm{CDCl}_{3} / \mathrm{CD}_{3} \mathrm{OD} 3: 1$, while the present spectra were acquired in $\mathrm{CD}_{3} \mathrm{OD}$ ). To confirm the nature and the absolute stereochemistry of the sugar moieties, an aliquot of $\mathbf{1}$ was hydrolyzed and reacted with (-)-2-butanol. ${ }^{14} \mathrm{GC}$ analysis revealed the presence of two D-galactose units, in agreement with Kashman's original findings. ${ }^{6}$ Since two further derivatives were obtained which displayed structural analogies to $\mathbf{1}$ (see below) two-dimensional NMR spectra were recorded for reference purposes. Careful inspection of the COSY and HMBC 
spectra (data not shown) allowed for a complete assignment of all signals, further corroborating that structure $\mathbf{1}$ is identical in all respects with eryloside A.

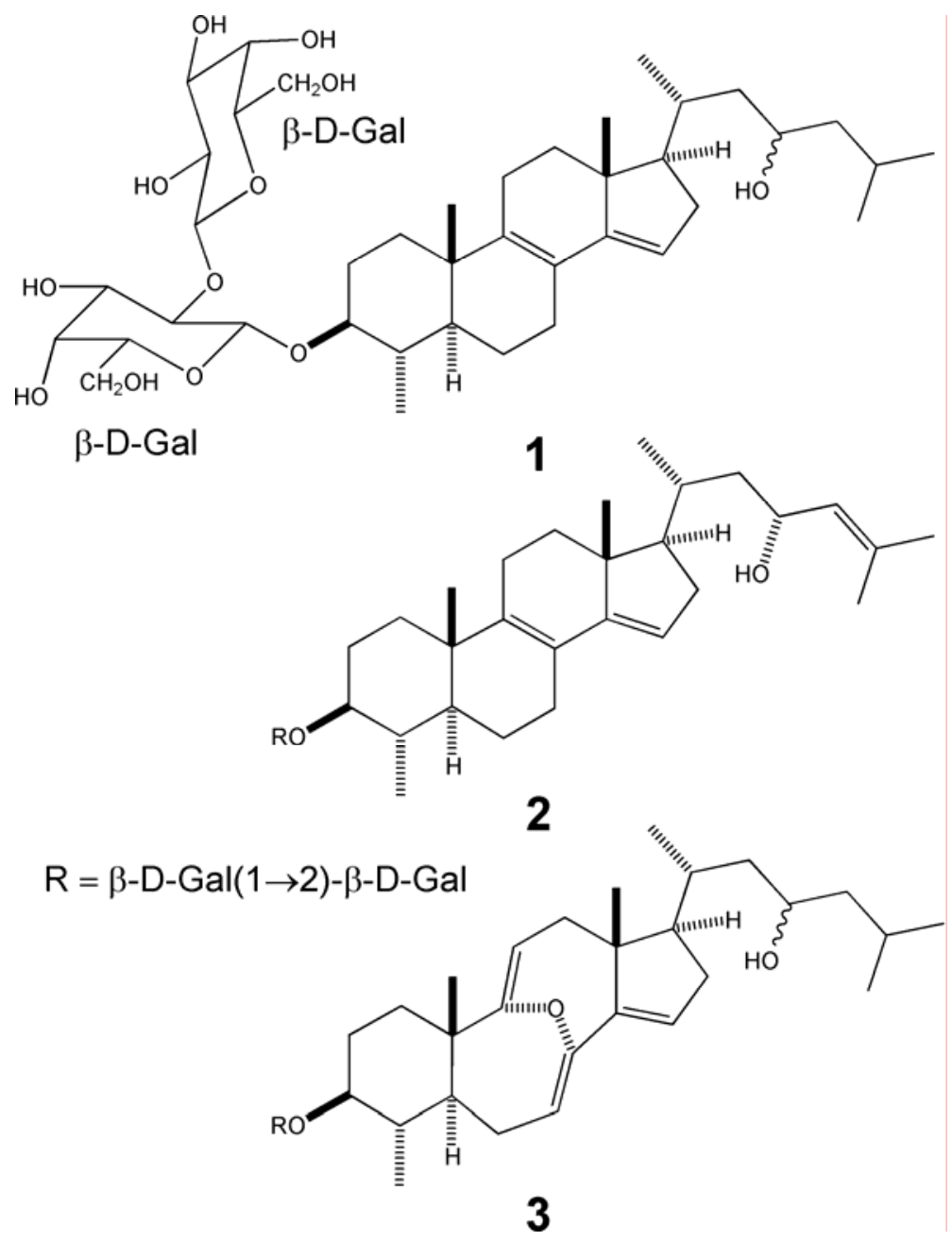

Figure 1. Structures of erylosides A (1), K (2), and L (3).

Eryloside K (2) displayed a pseudomolecular ion at $\mathrm{m} / \mathrm{z} 759.7[\mathrm{M}+\mathrm{Na}]^{+}$in $\mathrm{ESI}-\mathrm{LC} / \mathrm{MS}$, equivalent to a deficiency of two mass units as compared to eryloside A (1), thus suggesting the presence of an additional double bond. Fragment ions characteristic of a monodesmosidic steroidal saponin containing two hexose moieties appeared in a similar manner as described above for 1. From the ${ }^{1} \mathrm{H}$ NMR spectrum it was deduced that this additional degree of unsaturation had to be located in the side chain, because the signals corresponding to the sugar part or the steroid core were virtually identical to those observed for $\mathbf{1}$ (see Table 1). In comparison to $\mathbf{1}$, the signal for $\mathrm{H}-25$ was absent in 2 , while $\mathrm{H}-24(1 \mathrm{H})$ resonated at $\delta 5.22$, indicating that the double bond should reside at C-24 and C-25. This was also in agreement with the downfield shifts observed for $\mathrm{H}-23(\delta 4.46), \mathrm{H}_{3}-26(\delta 1.75)$, and $\mathrm{H}_{3}-27(\delta$ 1.72). These assignments were corroborated by the COSY spectrum which showed a strong correlation 
between $\mathrm{H}-23$ and the additional olefinic proton which in turn displayed allylic couplings to $\mathrm{H}_{3}$ 26 and $\mathrm{H}_{3}-27$. The gross structure 2 was also confirmed by the HMBC spectrum, although due to the limited amount of compound available, the observed correlations were mainly restricted to the methyl groups and the anomeric protons. The two sugar moieties in $\mathbf{2}$ were identified as Dgalactose, since the corresponding signals displayed strong similarities to the ${ }^{1} \mathrm{H}$ NMR spectrum of 1. Specifically, the observed coupling patterns for H-4' $(\delta 3.89$, dd, $J=3.4$ and $3.3 \mathrm{~Hz})$ and $\mathrm{H}-$ $4 "$ ( $\delta 3.76$, dd, $J=3.9$ and $3.4 \mathrm{~Hz}$ ) were supportive of this deduction. The linkage of the two galactose units was found to be identical to 1 through key HMBC correlations from $\mathrm{H}-1$ " to C-2', and $\mathrm{H}-1$ ' to $\mathrm{C}-3$, respectively.
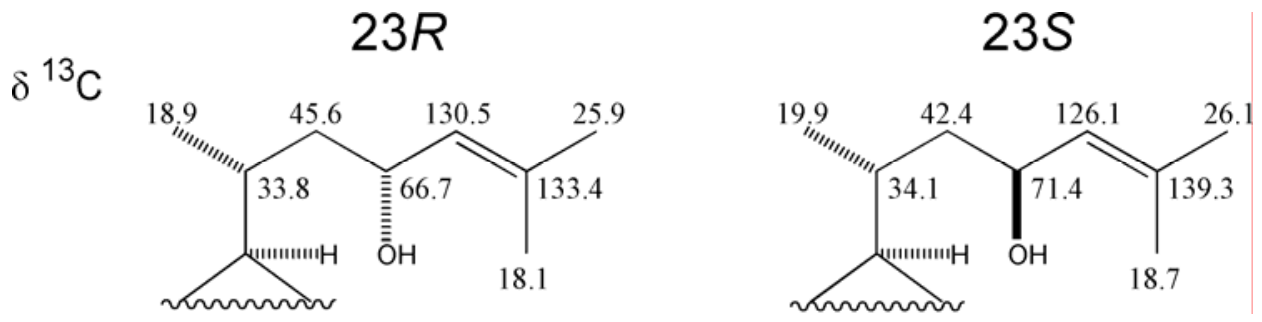

Figure 2. ${ }^{13} \mathrm{C}$ NMR data of reference compounds used to establish the absolute stereochemistry at C-23 in eryloside $\mathrm{K}(2)$ (data from lit. $^{15}$ and lit. ${ }^{16}$ ).

The absolute stereochemistry at C-23 in 2 was established by comparison with data published for both possible diastereomers. ${ }^{15,16}$ Cycloartenol sulfates $\mathbf{1}$ and $\mathbf{3}$ which had been isolated from the red alga Tricleocarpa fragilis and with the absolute configuration at C-23 assigned upon Mosher derivatization ${ }^{15}$ served as references for the $(23 R)$-stereochemistry; the euphane-type triterpene tridesmosides, rhoiptelesides $\mathrm{C}$ and $\mathrm{D}$, isolated from the leaves of the plant Rhoiptelea chiliantha represented the (23S)-series. The latter were originally isolated as 23-O- $\alpha$-Lrhamnopyranosides, but spectral characteristics were also published for the corresponding aglycones. ${ }^{16}$ Comparison of the ${ }^{13} \mathrm{C}$ NMR shifts of the side chain $(\mathrm{C}-20$ through $\mathrm{C}-27$, all measured in $\mathrm{CD}_{3} \mathrm{OD}$ ) revealed striking differences for the positions close to the asymmetric center at C-23 (Figure 2). Beside C-23, considerable variation in the range of 3-6 ppm was also observed for both olefinic carbons as well as for C-22. Thus, even though in the HMBC spectrum of 2 no correlation to C-23 could be observed, the chemical shifts of C-24 ( $\delta 130.3$ ) and $\mathrm{C}-25$ ( $\delta$ 133.4), evident through correlations from $\mathrm{H}_{3}-26$ and $\mathrm{H}_{3}-27$ on the one hand, and the chemical shifts of C-22 ( $\delta 45.0)$, obtained by a cross peak with $\mathrm{H}_{3}-21$ on the other hand, clearly indicate the $(23 R)$-configuration for eryloside $\mathrm{K}(2)$.

For Eryloside L (3), a pseudomolecular ion at $\mathrm{m} / \mathrm{z} 753.4[\mathrm{M}+\mathrm{H}]^{+}$was observed by ESI$\mathrm{LC} / \mathrm{MS}$, thus differing from eryloside $\mathrm{K}$ (2) by 16 mass units. The presence of an additional oxygen atom was confirmed by close inspection of the ${ }^{1} \mathrm{H}$ and ${ }^{13} \mathrm{C}$ NMR data which established the molecular formula $\mathrm{C}_{40} \mathrm{H}_{64} \mathrm{O}_{13}$. Again, the fragment ions obtained suggested 3 to be a monodesmosidic steroidal saponin containing two hexose moieties. In the ${ }^{1} \mathrm{H}$ NMR spectrum (see Table 1), three methine protons were observed in the downfield region at $\delta 5.43(\mathrm{H}-15)$, 
5.05 (H-11), and 4.85 (H-7, partly obscured by the residual water signal). The ${ }^{13} \mathrm{C}$ NMR and DEPT spectra displayed six signals for $\mathrm{sp}^{2}$-hybridized carbon atoms, including three quaternary carbons at $\delta 169.8(\mathrm{C}-9) ; 153.0(\mathrm{H}-8)$, and $151.5(\mathrm{H}-14)$, and three protic carbons at $\delta 122.9(\mathrm{C}-$ 15), 113.9 (C-7), and 107.4 (C-11). The respective protons attached to the latter were identified by inspection of the HMQC spectrum. So far, three out of the total of nine degrees of unsaturation implied by the molecular formula were accounted for, requiring the presence of six rings in the structure of 3 . From the ${ }^{1} \mathrm{H}$ and ${ }^{13} \mathrm{C}$ NMR spectra was concluded that 3 contained the same sugar moieties as found in $\mathbf{1}$ or $\mathbf{2}$, because the corresponding signals were almost superimposable. Thus, the steroid skeleton in $\mathbf{3}$ had to be tetracyclic which could only be explained by an insertion of the additional oxygen atom into the carbocyclic skeleton, because the ${ }^{1} \mathrm{H}$ and ${ }^{13} \mathrm{C}$ NMR signals assigned to the side chain $(\mathrm{C}-17$ through $\mathrm{C}-27)$ were virtually identical to the respective substructure present in eryloside A (1). From the COSY and TOCSY spectra, in addition to the two galactose residues three spin systems (a, $\mathbf{b}$, and $\mathbf{c})$ for the steroid core in $\mathbf{3}$ were clearly discernible, each terminated by one of the three methine functions (Figure 3). System a consists of $\mathrm{H}_{2}-1$ through $\mathrm{H}-7$, also including the branching methyl group $\mathrm{H}_{3}-28$ attached to C-4. System b comprises $\mathrm{H}-11, \mathrm{H}_{2}-12$, and $\mathrm{H}_{3}-18$ (through four-bond "W" coupling with $\mathrm{H}-12 \mathrm{~A}$ ), while c contains the side chain $\mathrm{H}-20$ through $\mathrm{H}_{3}-27$ in addition to $\mathrm{H}-17, \mathrm{H}_{2}-16$, and $\mathrm{H}-15$. Connection of these three substructures was established by key HMBC correlations from $\mathrm{H}_{3}-19$ to $\mathrm{C}-9, \mathrm{H}_{2}-12$ to $\mathrm{C}-9$ and $\mathrm{C}-14$, and $\mathrm{H}_{3}-18$ to $\mathrm{C}-14$ and $\mathrm{C}-17$. Thus, the steroid skeleton of eryloside L (3) was identified as $8 \alpha, 9 \alpha$-epoxy-4 $\alpha$-methyl-8,9-secocholesta-7,9(11), 14-triene. The stereochemistry of the bridging oxygen atom also explained the prominent downfield shift observed for H-5 ( $\delta 2.24)$ as compared to 1 and 2 ( $\delta 1.01$ and 1.10 , respectively). ${ }^{17}$ The UV spectrum of $\mathbf{3}$ lacks the typical diene bands observed for $\mathbf{1}$ or $\mathbf{2}$, which probably is due to the fact that the double bonds in $\mathbf{3}$ are twisted.
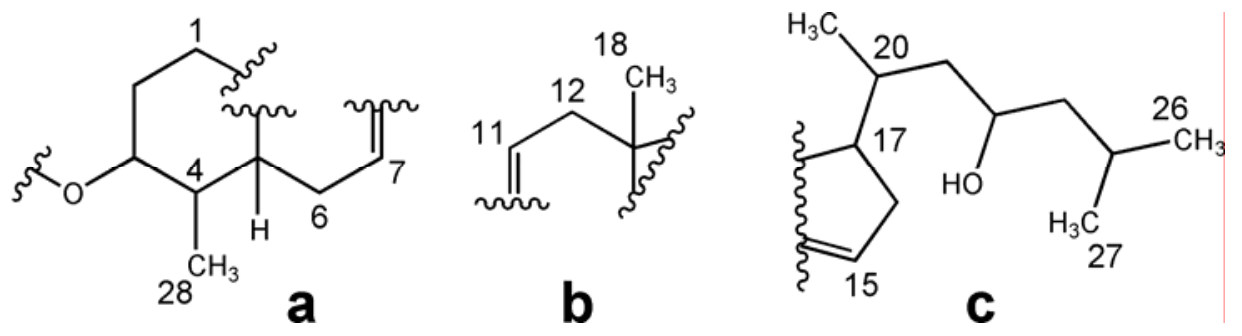

Figure 3. Substructures identified by COSY and TOCSY in the course of the structure elucidation of eryloside L (3).

The relative stereochemistry of eryloside L (3) was deduced from the observed nOes in the ROESY spectrum. For rings $\mathrm{A}$ and $\mathrm{B}$, the $\alpha$-orientation of $\mathrm{H}-3, \mathrm{H}-5$, and $\mathrm{H}_{3}-28$ was evident from mutual cross peaks of these protons on the one hand, and from a strong correlation between $\mathrm{H}_{3}$ 19 and $\mathrm{H}-4$ on the other hand. This was also confirmed by cross peaks from $\mathrm{H}-6 \mathrm{~A}$ to $\mathrm{H}_{3}-28$, and $\mathrm{H}-6 \mathrm{~B}$ to $\mathrm{H}_{3}-19$. The relative stereochemistry at rings $\mathrm{C}$ and $\mathrm{D}$ was apparent from mutual 
correlations from $\mathrm{H}_{3}-18$ to $\mathrm{H}-12 \mathrm{~B}$ and $\mathrm{H}-16 \mathrm{~B}$, and from $\mathrm{H}_{3}-17$ to $\mathrm{H}-12 \mathrm{~A}, \mathrm{H}-16 \mathrm{~A}$, and $\mathrm{H}-21$. Finally, in agreement with previous findings, ${ }^{18}$ the $8 \alpha, 9 \alpha$-position of the oxygen bridge was deduced from a cross peak between $\mathrm{H}-11$ and $\mathrm{H}_{3}-19$, in conjunction with the above mentioned prominent downfield shift observed for $\mathrm{H}-5 .^{17}$

Table 1. NMR data for erylosides A (1), K (2), and L (3)

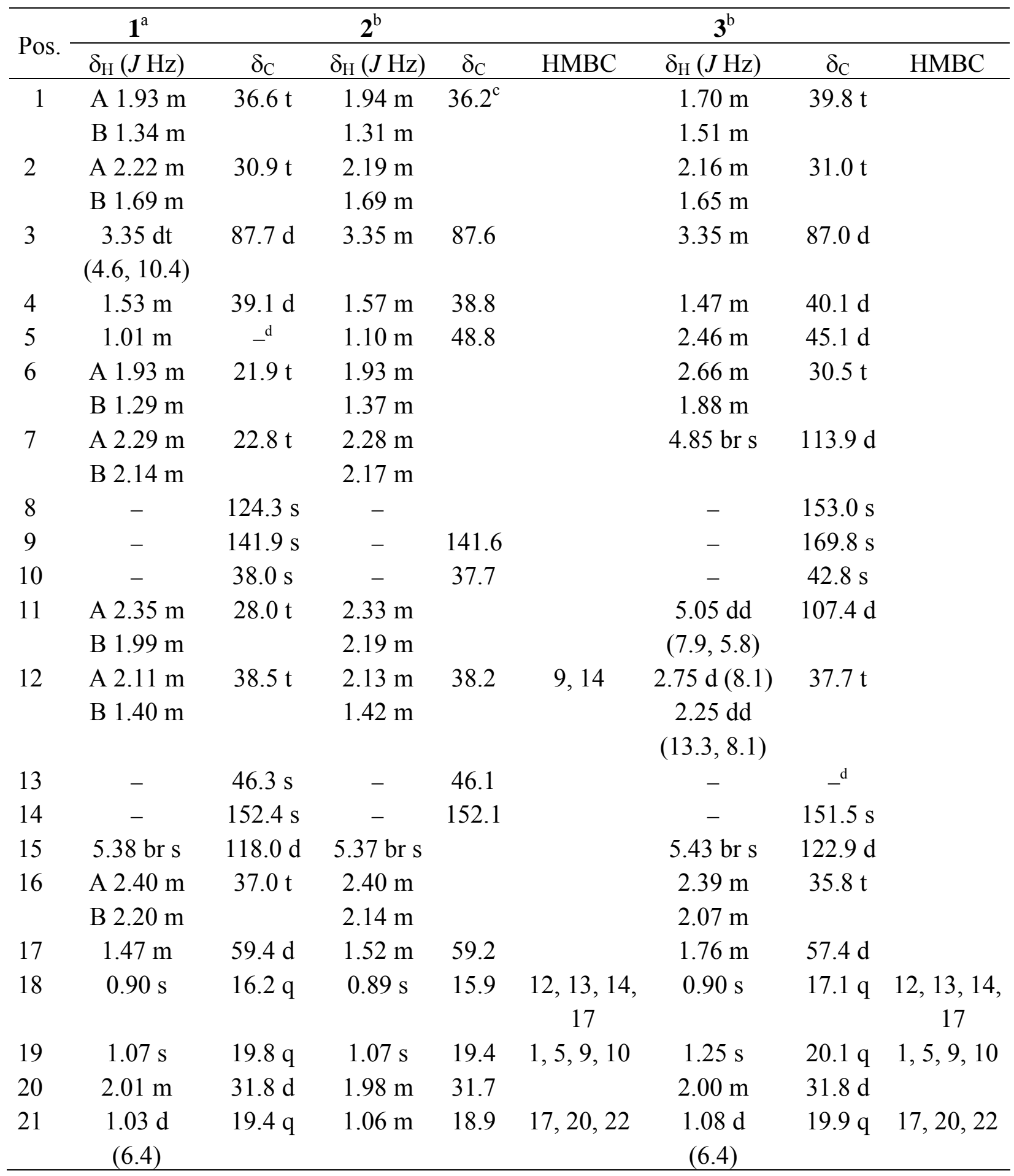


Table 1. continued

\begin{tabular}{|c|c|c|c|c|c|c|c|c|}
\hline \multirow{2}{*}{ Pos. } & \multicolumn{4}{|c|}{$2^{b}$} & \multicolumn{3}{|c|}{$3^{b}$} & \multirow[b]{2}{*}{ HMBC } \\
\hline & $\delta_{\mathrm{H}}(\mathrm{J} \mathrm{Hz})$ & $\delta_{\mathrm{C}}$ & $\delta_{\mathrm{H}}(\mathrm{J} \mathrm{Hz})$ & $\delta_{C}{ }^{c}$ & HMBC & $\delta_{\mathrm{H}}(\mathrm{J} \mathrm{Hz})$ & $\delta_{\mathrm{C}}$ & \\
\hline \multirow[t]{2}{*}{22} & A $1.56 \mathrm{~m}$ & $45.5 \mathrm{t}$ & $1.70 \mathrm{~m}$ & 45.0 & & $1.58 \mathrm{~m}$ & $45.4 \mathrm{t}$ & \\
\hline & B $1.22 \mathrm{~m}$ & & $1.03 \mathrm{~m}$ & & & $1.13 \mathrm{~m}$ & & \\
\hline 23 & $3.63 \mathrm{~m}$ & $67.4 \mathrm{~d}$ & $4.46 \mathrm{~m}$ & & & $3.76 \mathrm{~m}$ & $67.5 \mathrm{~d}$ & \\
\hline \multirow[t]{2}{*}{24} & A $1.43 \mathrm{~m}$ & $-{ }^{\mathrm{d}}$ & $5.22 \mathrm{dt}$ & 130.3 & & $1.43 \mathrm{~m}$ & $49.1 \mathrm{t}$ & \\
\hline & B $1.18 \mathrm{~m}$ & & $(8.4,1.2)$ & & & $1.22 \mathrm{~m}$ & & \\
\hline 25 & $1.81 \mathrm{~m}$ & $25.8 \mathrm{~d}$ & - & 133.2 & & $1.81 \mathrm{~m}$ & $25.8 \mathrm{~d}$ & \\
\hline 26 & $\begin{array}{c}0.96 \mathrm{~d} \\
(6.5)\end{array}$ & $22.7 \mathrm{q}^{\mathrm{e}}$ & $\begin{array}{c}1.75 \mathrm{~d} \\
(1.1)\end{array}$ & 25.7 & $24,25,27$ & $\begin{array}{c}0.99 \mathrm{~d} \\
(6.6)\end{array}$ & $22.6 \mathrm{q}$ & $24,25,27$ \\
\hline 27 & $\begin{array}{c}0.96 \mathrm{~d} \\
(6.5)\end{array}$ & $23.7 \mathrm{q}^{\mathrm{e}}$ & $\begin{array}{c}1.72 \mathrm{~d} \\
(1.0)\end{array}$ & 17.8 & $24,25,26$ & $\begin{array}{c}0.99 \mathrm{~d} \\
(6.6)\end{array}$ & $23.7 \mathrm{q}$ & $24,25,26$ \\
\hline 28 & $\begin{array}{c}1.13 \mathrm{~d} \\
(6.3)\end{array}$ & $15.9 \mathrm{q}$ & $\begin{array}{c}1.14 \mathrm{~d} \\
(6.3)\end{array}$ & 15.7 & $3,4,5$ & $\begin{array}{c}1.17 \mathrm{~d} \\
(6.3)\end{array}$ & $16.4 \mathrm{q}$ & $3,4,5$ \\
\hline $1^{\prime}$ & $\begin{array}{c}4.48 \mathrm{~d} \\
(7.6)\end{array}$ & $104.7 \mathrm{~d}$ & $\begin{array}{c}4.48 \mathrm{~d} \\
(7.8)\end{array}$ & 104.6 & 3 & $\begin{array}{c}4.48 \mathrm{~d} \\
(7.7)\end{array}$ & $104.7 \mathrm{~d}$ & 3 \\
\hline $2^{\prime}$ & $\begin{array}{c}3.86 \mathrm{dd} \\
(9.2,7.6)\end{array}$ & $80.5 \mathrm{~d}$ & $\begin{array}{c}3.85 \mathrm{dd} \\
(9.4,7.8)\end{array}$ & 80.3 & & $\begin{array}{c}3.84 \mathrm{dd} \\
(9.5,7.7)\end{array}$ & $80.6 \mathrm{~d}$ & 1', 1" \\
\hline $3^{\prime}$ & $3.69 \mathrm{~m}$ & $75.2 \mathrm{~d}$ & $3.70 \mathrm{~m}$ & & & $3.60 \mathrm{~m}$ & $75.2 \mathrm{~d}$ & \\
\hline $4^{\prime}$ & $\begin{array}{c}3.88 \text { br d } \\
\quad(3.6)\end{array}$ & $70.1 \mathrm{~d}$ & $\begin{array}{c}3.88 \mathrm{dd} \\
(3.5,0.8)\end{array}$ & $69.9^{\mathrm{e}}$ & & $\begin{array}{c}3.88 \text { br d } \\
(3.3)\end{array}$ & $70.1 \mathrm{~d}$ & \\
\hline $5^{\prime}$ & $3.56 \mathrm{~m}$ & $76.3 \mathrm{~d}$ & $3.55 \mathrm{~m}$ & 76.2 & & $3.53 \mathrm{~m}$ & $76.3 \mathrm{~d}$ & $1^{\prime}$ \\
\hline \multirow[t]{2}{*}{$6^{\prime}$} & A $3.77 \mathrm{~m}$ & $62.2 \mathrm{t}^{\mathrm{e}}$ & $3.80 \mathrm{~m}$ & $62.0^{f}$ & & $3.69 \mathrm{~m}$ & $62.2 \mathrm{t}^{\mathrm{e}}$ & \\
\hline & B $3.77 \mathrm{~m}$ & & $3.79 \mathrm{~m}$ & & & $3.72 \mathrm{~m}$ & & \\
\hline $1 "$ & $\begin{array}{c}4.60 \mathrm{~d} \\
(7.6)\end{array}$ & $105.7 \mathrm{~d}$ & $\begin{array}{c}4.61 \mathrm{~d} \\
(7.8)\end{array}$ & 105.7 & $2^{\prime}$ & $\begin{array}{l}4.60 \mathrm{~d} \\
(7.8)\end{array}$ & $105.8 \mathrm{~d}$ & $2^{\prime}$ \\
\hline $2 "$ & $\begin{array}{c}3.67 \mathrm{dd} \\
(9.7,7.6)\end{array}$ & $73.1 \mathrm{~d}$ & $\begin{array}{c}3.68 \mathrm{dd} \\
(9.7,7.8)\end{array}$ & 73.4 & & $\begin{array}{c}3.67 \mathrm{dd} \\
(9.7,7.8)\end{array}$ & $73.2 \mathrm{~d}$ & \\
\hline $3 "$ & $3.55 \mathrm{~m}$ & $74.8 \mathrm{~d}$ & $3.53 \mathrm{~m}$ & 74.7 & & $3.54 \mathrm{~m}$ & $74.9 \mathrm{~d}$ & $1 "$ \\
\hline 4" & $3.74 \mathrm{~m}$ & $70.1 \mathrm{~d}$ & $3.76 \mathrm{~m}$ & $69.9^{\mathrm{e}}$ & & $3.71 \mathrm{~m}$ & $70.1 \mathrm{~d}$ & \\
\hline $5^{\prime \prime}$ & $3.55 \mathrm{~m}$ & $77.1 \mathrm{~d}$ & $3.58 \mathrm{~m}$ & 76.9 & & $3.59 \mathrm{~m}$ & $77.1 \mathrm{~d}$ & \\
\hline \multirow[t]{2}{*}{ 6" } & A $3.67 \mathrm{~m}$ & $62.3 \mathrm{t}^{\mathrm{e}}$ & $3.74 \mathrm{~m}$ & $62.2^{\mathrm{f}}$ & & $3.69 \mathrm{~m}$ & $62.3 \mathrm{t}^{\mathrm{e}}$ & \\
\hline & $3.67 \mathrm{~m}$ & & $3.72 \mathrm{~m}$ & & & $3.72 \mathrm{~m}$ & & \\
\hline
\end{tabular}

${ }^{a}$ Measured at 400 and $100 \mathrm{MHz}$, respectively. ${ }^{\mathrm{b}}$ Measured at 600 and $150 \mathrm{MHz}$, respectively.

${ }^{c}$ Extracted from the HMBC spectrum. ${ }^{d}$ Obscured by solvent or water peak. ${ }^{\text {e,f }}$ May be interchanged. 
A similar approach as described above for eryloside K (2) for the assignment of the absolute stereochemistry at C-23 in $\mathbf{3}$ proved unsuccessful, because even though examples for both possible diastereomers have been published, for example from starfishes, ${ }^{19,20}$ their available ${ }^{1} \mathrm{H}$ or ${ }^{13} \mathrm{C}$ NMR data are too similar and do not allow for an unequivocal distinction between (23R)or (23S)-configuration. For this reason, like in the original publication of eryloside $\mathrm{A},{ }^{6}$ the absolute stereochemistry at C-23 for both 1 and eryloside L (3) has to remain open at this point.

The novel erylosides K (2) and L (3) are more related to the parent compound, eryloside A (1) than to any other member of this saponin series, both with regard to the identical sugar moieties as well as in terms of the $4 \alpha$-methyl-cholesta-8,14-diene-3,23-diol steroid core. While eryloside $\mathrm{K}(2)$ is the 24,25-didehydro congener of $\mathbf{1}$, the carbon skeleton of eryloside L (3) is rearranged to an unusual $8 \alpha, 9 \alpha$-epoxy-4 $\alpha$-methyl-8,9-secocholesta-7,9(11),14-triene system, which to the best of our knowledge has never been described for a natural product before. Similar oxygen-bridged 8,9-secosteroids lacking the additional 14,15-double bond have been described for marine sponges. Jereisterol A featuring a 3-methoxy function and a 24-methyl substituent in the nonhydroxylated side chain was described for the New Caledonian sponge, Jereicopsis graphidiophora. ${ }^{17}$ Later, the corresponding 24-ethyl homologue was isolated from the Senegalese sponge, Microscleroderma spirophora. ${ }^{18}$ More recently, a structurally related ergostane-derived 8,9-epoxy-8,9-secosteroid has been obtained from a higher basidiomycete fungus, Tylopilus plumbeoviolaceus. ${ }^{21}$ Interestingly, during early photooxygenation studies of $3 \beta$-acetoxylanost-8-ene, among other products, the Criegee rearrangement product $3 \beta$-acetoxy8,9-epoxy-8,9-secolanosta-7,9(11)-diene has been synthesized, ${ }^{22}$ but the reaction conditions applied (reaction conducted in pyridine in the presence of $p$-nitrobenzenesulfonyl chloride and hematoporphyrin) were probably too harsh to consider the above mentioned natural products as simple oxidation artifacts of corresponding unsaturated steroid precursors with intact carbon skeletons.

When tested for biological activity, eryloside A (1) displayed mild antibiotic and antifungal activity against E. coli, B. subtilis, and C. albicans. The respective zones of inhibition at $10 \mu \mathrm{g}$ per disc measured 6,7 , and $7 \mathrm{~mm}$, respectively, while no activity was observed at $5 \mu \mathrm{g}$ per disc. Furthermore, in the brine shrimp assay, 1 and 2 lead to a mortality rate of 50\% when tested at a concentration of $0.1 \mathrm{mg} / \mathrm{mL}$. At the same concentration, compound 3 was inactive. For eryloside A (1), an antitumor activity against P-388 cells with an $\mathrm{IC}_{50}=4.2 \mu \mathrm{g} / \mathrm{mL}$ has been reported, ${ }^{6}$ and erylosides G-J displayed moderate cytotoxicity against the human leukemia cell line K562. ${ }^{12}$ However, when tested against the JURKAT, THP-1, and MM-1 cell lines, we could not detect any cytotoxic activity for the compounds investigated in the present study.

For other members of the eryloside family, interesting pharmacological properties have also been reported. While eryloside $\mathrm{F}$ shows a potent and relatively selective thrombin receptor antagonist activity and inhibits human platelet aggregation in vitro, ${ }^{9}$ eryloside $\mathrm{E}$ displays immunosuppressive activity, ${ }^{8}$ and nobiloside is a neuraminidase inhibitor. ${ }^{13}$ From an ecological point of view, the mixtures of eryloside-type triterpenes from Carribean collections have been shown to contribute to the chemical defense of the sponge Erylus formosus. Beside a fish 
deterrent activity against both Thalassoma bifasciatum in aquarium experiments as well as the natural reef fish community in field assays, ${ }^{23}$ inhibition of bacterial attachment and fouling propagules were detected. ${ }^{24}$ Interestingly, at least in some of these experiments, the naturally occurring triterpene mixture was more active than the individual isolated pure compounds, indicating a potential synergistic effect. At any rate, it can be concluded that in the Carribean erylosides fulfill multiple ecological roles. ${ }^{24}$

\section{Experimental Section}

General Procedures. Optical rotations were measured on a Perkin- Elmer Model 341 LC polarimeter. ${ }^{1} \mathrm{H}$ NMR and ${ }^{13} \mathrm{C}$ NMR experiments were performed on Bruker Unity 400 and $600 \mathrm{MHz}$ spectrometers. NMR spectra were referenced to the $\mathrm{CD}_{3} \mathrm{OD}$ solvent signals at $\delta 3.30$ $\left({ }^{1} \mathrm{H}\right)$ and $49.00\left({ }^{13} \mathrm{C}\right)$, respectively. ESI mass spectra were obtained with a Thermofinnigan LCQ DECA mass spectrometer coupled to an Agilent 1100 HPLC system equipped with a photodiode array detector. HRESI-MS were determined with a Micromass Qtof 2 mass spetrometer. HPLC separations were performed on an HPLC system consisting of a Lachrom-Merck Hitachi L-7100 pump and a L-7400 UV detector using a C-18 column $(300 \times 8 \mathrm{~mm}$ i.d., prefilled with Eurospher 100, Knauer, Berlin, Germany), a flow rate of $5.0 \mathrm{~mL} / \mathrm{min}$, and UV detection at $249 \mathrm{~nm}$. GC analyses were carried out on an Agilent 6850 series gas chromatograph using an HP-5 column (crosslinked 5\% PHM / Siloxan, Macherey und Nagel, Düren, Germany) and a flame ionization detector. Column chromatography was performed on silica gel $60(0.040-0.063 \mathrm{~mm})$, or RP-18 Lobar $^{\circledR}$ columns $(40-63 \mu \mathrm{m}, 310 \mathrm{~mm} \times 15 \mathrm{~mm}$ i.d), and TLC analysis were carried out on aluminum sheets precoated with silica gel $60 \mathrm{~F}_{254}$ (Merck, Darmstadt, Germany). TLC visualization was by UV absorption at $254 \mathrm{~nm}$. All solvents were distilled prior to use. Spectral grade solvents were utilized for chromatographic analysis.

Extraction and isolation. The marine sponge Erylus lendenfeldi Thiele (order: Astrophorida, family: Geodiidae) was collected from the Gulf of Aqaba, Red Sea in September 2000 by the staff of the marine science station in Jordan. The sponge was frozen immediately after collection and stored until extraction. The taxonomic identification was carried out by Dr. Rob van Soest (Zoological Museum, Amsterdam).

The organic extract of Erylus lendenfeldi (11.74 g) was subjected to solvent-solvent partitioning using $\mathrm{CH}_{2} \mathrm{Cl}_{2}$, EtOAc and $n-\mathrm{BuOH}$. The EtOAc and $n$-BuOH fractions were combined and evaporated under reduced pressure until dryness. The residue was subjected to MPLC on silica gel using $\mathrm{CH}_{2} \mathrm{Cl}_{2} / \mathrm{MeOH}$ (7:3) as eluent to give three fractions. Fraction 2 was rechromatographed on a RP-18 Lobar $^{\circledR}$ column using $\mathrm{MeOH} / \mathrm{H}_{2} \mathrm{O}$ (9:1). Final purification was achieved by semipreparative HPLC on RP-18 with $\mathrm{MeOH}$ and $\mathrm{H}_{2} \mathrm{O}$ using the following eluent gradient: 0$5 \mathrm{~min}, 10 \% \mathrm{MeOH}$; 5-25 min, 10-85\% MeOH, 25-30 min, 85-100\% MeOH to give eryloside A (1) (7.5 mg), eryloside K (2) (1.8 mg), and eryloside L (3) (5.2 mg). 
Eryloside A (1). White amorphous powder; $[\alpha]_{\mathrm{D}}^{20}+11.0($ c $0.3, \mathrm{MeOH}) ; \mathrm{UV}(\mathrm{MeOH}): \lambda_{\max }$ $251 \mathrm{~nm} ;{ }^{1} \mathrm{H}$ and ${ }^{13} \mathrm{C}$ NMR: Table 1; ESI-MS (pos): $\mathrm{m} / \mathrm{z}(\%) 761.7$ (43) $[\mathrm{M}+\mathrm{Na}]^{+}, 739.3$ (41) $[\mathrm{M}+\mathrm{H}]^{+}, 577.4(35)\left[\mathrm{M}+\mathrm{H}-\mathrm{C}_{6} \mathrm{H}_{10} \mathrm{O}_{5}\right]^{+}, 415.5$ (79) $\left[\mathrm{M}+\mathrm{H}-2 \times \mathrm{C}_{6} \mathrm{H}_{10} \mathrm{O}_{5}\right]^{+}, 397.5$ (100) $[\mathrm{M}+\mathrm{H}-$ $\left.2 \times \mathrm{C}_{6} \mathrm{H}_{10} \mathrm{O}_{5}-\mathrm{H}_{2} \mathrm{O}\right]^{+}$; (neg): $\mathrm{m} / \mathrm{z}(\%) 784.1(100)[\mathrm{M}-\mathrm{H}+\mathrm{HCOOH}]^{-}, 738.1$ (18) [M-H]

Eryloside K (2). White amorphous powder; $[\alpha]_{\mathrm{D}}^{20}+6.1$ (c $\left.0.2, \mathrm{MeOH}\right)$; UV (MeOH): $\lambda_{\max }$ $251 \mathrm{~nm} ;{ }^{1} \mathrm{H}$ and ${ }^{13} \mathrm{C}$ NMR: Table 1; ESI-MS (pos): $\mathrm{m} / \mathrm{z}(\%) 759.7$ (24) $[\mathrm{M}+\mathrm{Na}]^{+}, 719.6$ (100) $\left[\mathrm{M}+\mathrm{H}-\mathrm{H}_{2} \mathrm{O}\right]^{+}, 557.6(15)\left[\mathrm{M}+\mathrm{H}-\mathrm{H}_{2} \mathrm{O}-\mathrm{C}_{6} \mathrm{H}_{10} \mathrm{O}_{5}\right]^{+}, 395.6(39)\left[\mathrm{M}+\mathrm{H}-\mathrm{H}_{2} \mathrm{O}-2 \times \mathrm{C}_{6} \mathrm{H}_{10} \mathrm{O}_{5}\right]^{+}, 377.6$ (15) $\left[\mathrm{M}+\mathrm{H}-2 \times \mathrm{H}_{2} \mathrm{O}-2 \times \mathrm{C}_{6} \mathrm{H}_{10} \mathrm{O}_{5}\right]^{+}$; (neg): $\mathrm{m} / \mathrm{z}(\%) 782.1$ (100) $[\mathrm{M}-\mathrm{H}+\mathrm{HCOOH}]^{-}, 736.4$ (16) $[\mathrm{M}-\mathrm{H}]^{-}$. Eryloside L (3). White amorphous powder; $[\alpha]_{D}^{20}+23.0$ (c $\left.0.2, \mathrm{MeOH}\right)$; UV (MeOH): $\lambda_{\max }$ $202 \mathrm{~nm} ;{ }^{1} \mathrm{H}$ and ${ }^{13} \mathrm{C}$ NMR: Table 1; ESI-MS (pos): $\mathrm{m} / \mathrm{z}(\%) 775.4$ (39) $[\mathrm{M}+\mathrm{Na}]^{+}, 753.4$ (72) $[\mathrm{M}+\mathrm{H}]^{+}, 591.5(42)\left[\mathrm{M}+\mathrm{H}-\mathrm{C}_{6} \mathrm{H}_{10} \mathrm{O}_{5}\right]^{+}, 429.5(100)\left[\mathrm{M}+\mathrm{H}-2 \times \mathrm{C}_{6} \mathrm{H}_{10} \mathrm{O}_{5}\right]^{+}, 411.6$ (77) [M+H$\left.2 \times \mathrm{C}_{6} \mathrm{H}_{10} \mathrm{O}_{5}-\mathrm{H}_{2} \mathrm{O}\right]^{+}$; (neg): $\mathrm{m} / \mathrm{z}(\%) 798.0$ (100) $[\mathrm{M}-\mathrm{H}+\mathrm{HCOOH}]^{-}, 752.3$ (16) $[\mathrm{M}-\mathrm{H}]^{-}$.

Acid hydrolysis and GC analysis. ${ }^{14}$ A solution of eryloside A (1) (1.5 mg) in methanol (25 mL) was treated with $3 \mathrm{~N} \mathrm{HCl}(15 \mathrm{~mL})$ and stirred at $80{ }^{\circ} \mathrm{C}$ for $5 \mathrm{~h}$. Upon drying with a flow of nitrogen, the residue was dissolved in $(-)$-2-butanol $(0.5 \mathrm{~mL})$ and one drop of trifluoroacetic acid. The solution was transferred to an ampoule which was sealed and heated at $130{ }^{\circ} \mathrm{C}$ in an oven overnight until complete butanolysis. After being taken to dryness, the resulting residue was reacted with hexamethyldisilazane/chlorotrimethylsilane/pyridine $(1: 1: 5,0.1 \mathrm{~mL}$, ) for 30 min at room temperature. The solution was then centrifuged and the supernatant $(1 \mu \mathrm{L})$ was analysed by GC using an HP-5 column. The injection port and detector temperatures were set at $200{ }^{\circ} \mathrm{C}$ and $220{ }^{\circ} \mathrm{C}$, respectively. A temperature gradient from $135^{\circ} \mathrm{C}$ to $200{ }^{\circ} \mathrm{C}$ at $1{ }^{\circ} \mathrm{C} / \mathrm{min}$ was applied. For the hydrolysate, four peaks were detected at 37.49, 40.11, 42.43, and $43.49 \mathrm{~min}$. Authentic standards prepared in a similar manner from commercially available D- and Lgalactose gave rise to peaks at 37.50, 40.15, 42.44, and $43.45 \mathrm{~min}$ and 38.34, 40.16, 42.42, and 43.90 min, respectively.

Agar diffusion assays. Susceptibility disks $(5 \mathrm{~mm}$ in diameter) were impregnated with a solution of the isolated compounds ( 5 and $10 \mu \mathrm{g}$ ) in $\mathrm{MeOH}$ (5 and $10 \mu \mathrm{l}$, respectively). Upon evaporation of the solvent, disks were placed on LB agar plates inoculated with the test bacteria B. subtilis 168, S. aureus ATCC 25923, and E. coli ATCC 25922. The plates were observed for zones of inhibition, after $24 \mathrm{~h}$ of incubation at $37^{\circ} \mathrm{C}$. The compounds were also assayed using $C$. albicans as test organism which was inoculated on YPD agar plates and zones of inhibition were recorded after $24 \mathrm{~h}$ of incubation at $37{ }^{\circ} \mathrm{C}$. In all cases, for the controls containing only the respective amount of solvent, no zones of inhibition were observed.

\section{Acknowledgements}

M. F. wishes to thank the Egyptian Government for a scholarship. We wish to thank the staff of the marine science station, Aqaba, Jordan for the collection of the sponge. We are indebted to Gernot Bauers and B. Steffan (all Institut für Pharmazeutische Biologie, Düsseldorf) for their 
help with antibacterial assays, to Dr. Klaus Steube (Deutsche Sammlung von Mikroorganismen und Zellkulturen, Braunschweig, Germany) for cytotoxicity testing, and to Dr. Rob van Soest (Zoological Museum, University of Amsterdam) for the identification of the sponge.

\section{References}

1. Fusetani, N.; Sata, N.; Asai, N.; Matsunaga, S. Tetrahedron Lett. 1993, 34, 4067.

2. Sata, N.; Asai, N.; Matsunaga, S.; Fusetani, N. Tetrahedron 1994, 50, 1105.

3. Goobes, R.; Rudi, A.; Kashman, Y.; Ilan, M.; Loya, Y. Tetrahedron 1996, 52, 7921.

4. Carballeira, N. M.; Negron, V. J. Nat. Prod. 1991, 54, 305.

5. van Altena, I.; van Soest, R.; Roberge, M.; Andersen, R. J. J. Nat. Prod. 2003, 66, 561.

6. Carmely, S.; Roll, M.; Loya, Y.; Kashman, Y. J. Nat. Prod. 1989, 52, 167.

7. D’Auria, M. V.; Paloma, L. G.; Minale, L.; Riccio, R.; Debitus, C. Tetrahedron 1992, 48, 491.

8. Gulavita, N. K.; Wright, A. E.; Kelly-Borges, M.; Longley, R. E.; Yarwood, D.; Sills, M. A. Tetrahedron Lett. 1994, 35, 4299.

9. Stead, P.; Hiscox, S.; Robinson, P. S.; Pike, N. B.; Sidebottom, P. J.; Roberts, A. D.; Taylor, N. L.; Wright, A. E.; Pomponi, S. A.; Langley, D. Bioorg. Med. Chem. Lett. 2000, 10, 661.

10. Jaspars, M.; Crews, P. Tetrahedron Lett. 1994, 35, 7501.

11. Kubanek, J.; Fenical, W.; Pawlik, J. R. Nat. Prod. Lett. 2001, 15, 275.

12. Shin, J.; Lee, H. S.; Woo, L.; Rho, J. R.; Seo, Y.; Cho, K. W.; Sim, C. J. J. Nat. Prod. 2001, 64, 767.

13. Takada, K.; Nakao, Y.; Matsunaga, S.; van Soest, R.; Fusetani, N. J. Nat. Prod. 2002, 65, 411.

14. Gerwig, G. J.; Kamerling, J. P.; Vliegenthart, J. F. G. Carbohyd. Res. 1978, 62, 349.

15. Horgen, F. D.; Sakamoto, B.; Scheuer, P. J. J. Nat. Prod. 2000, 63, 210.

16. Jiang, Z. H.; Tanaka, T.; Kouno, I. Chem. Pharm. Bull. 1999, 47, 101.

17. D’Auria, M. V.; Paloma, L. G.; Minale, L.; Riccio, R.; Debitus, C. Tetrahedron Lett. 1991, 32, 2149.

18. Costantino, V.; Fattorusso, E.; Mangoni, A.; Aknin, M.; Gaydou, E. M. Steroids 1994, 59, 181.

19. Finamore, E.; Zollo, F.; Minale, L.; Yasumoto, T. J. Nat. Prod. 1992, 55, 767.

20. Iorizzi, M.; Minale, L.; Riccio, R.; Yasumoto, T. J. Nat. Prod. 1993, 56, 1786.

21. Wu, S. H.; Luo, X. D.; Ma, Y. B.; Liu, J. K.; Wu, D. G.; Zhao, B.; Lu, Y., Zheng, Q. T. J. Nat. Prod. 2000, 63, 534.

22. Fox, J. E.; Scott, A. I.; Young, D. W. Chem. Comm. 1967, 21, 1105.

23. Kubanek, J.; Pawlik, J. R.; Eve, T. M.; Fenical, W. Mar. Ecol. Progr. Ser. 2000, 207, 69.

24. Kubanek, J.; Whalen, K. E.; Engel, S.; Kelly, S. R.; Henkel, T. P.; Fenical, W.; Pawlik, J. R. Oecologia 2002, 131, 125. 